\title{
Cross-cultural Theatre Education: Rehearsals and Performance English as Lingua Franca, rewriting process, and poly-glottal text in psycho-physical acting practice
}

\section{LARS HENNING}

\begin{abstract}
At Copenhagen International School of Performing Arts, English is the Lingua Franca (ELF) of artistic exploration. With a non-conformist approach to the use of ELF, highlighting a body-mind insight into the language over correctness, a latent, expressive potential of ELF is explored through a psycho-physical training. The predominant technique is Movement Psychology (Laban/Malmgren), which examines the interdependence between, on the one hand, text, language, and narrative and, on the other, the embodiment of the Jungian unconscious.

The paper analyses the process and the methods of staging the production entitled Re: ORESTES, based on Mee's play Orestes 2.0, applying the described methodological exploration. The play was rewritten and remoulded by the performers throughout a rehearsal process, which focused on interlacing the performers' highly diverse cultural horizons (Gadamer) in a common mega-text, in an attempt to fuse the familiar with the alien, the personal with the collective, and to channel, shape and articulate the material within ELF.

The paper details two different examples of this transformative remoulding process. One actor wrote a completely new text, which was performed in the heightened style of "the Queen's English". Another actor performed a part in a poly-glottal combination of Ancient and Modern Greek (her mother tongue) and ELF. In this process, both performers sought to transcend the preconceived limitations of their individual cultural horizons as well as of the English language.
\end{abstract}

\section{KEYWORDS}

Cross-cultural theatre education, English as Lingua Franca, movement psychology, psycho-physical actor training, embodiment of the unconscious 


\section{Cross-cultural Theatre Education: Rehearsals and Performance English as Lingua Franca, rewriting process, and poly-glottal text in psycho- physical acting practice}

This paper documents and analyses the process and the methods of staging the production entitled Re: ORESTES, based on Charles Mee's play Orestes 2.0. after Euripides's antique version. The play was rewritten and remoulded by the performers, resulting in a post-dramatic use of various styles. Re: ORESTES was performed in a warehouse at the Carlsberg City, Copenhagen, the historical site of the breweries, in May/June of 2015, with a cast of ten multilingual performers. The re-creative rehearsal process lasted for approximately eight weeks. The educational and aesthetic aim of this remoulding process was to fuse a multitude of cultural horizons among the performers. The process was embedded into the framework of the psycho-physical actor training programme at the Copenhagen International School of Performing Arts (CISPA), which examines the interdependence between text/language/narrative and the embodiment of the unconscious, in Jungian terms. ${ }^{1}$

\section{MAIN EDUCATIONAL PRINCIPLES AND METHODS:}

\section{English as Lingua Franca, Movement Psychology, Action Research}

When in 2012, a team of teachers within Acting Technique, Movement, Movement Psychology, Singing and Voice Training decided to set up CISPA, an international performing arts school with a professional three year acting course, one of the main aims was to develop a contemporary, methodological actor training, which would enable students, working and performing in English as Lingua Franca (ELF), to respond competently and confidently to a new set of global, cross-cultural challenges in their artistic endeavours. One 
of the largest (and most exciting) challenges is that of finding a common platform in a multinational context with regards to a clearly defined, yet inclusive and adaptable methodology, and to a fusion of the diverse cultural horizons, reaching a common approach to working and performing in ELF, and a common artistic expressivity, that is language in a broader sense: movement, gesture, vocality. ${ }^{2}$

\section{ENGLISH AS LINGUA FRANCA}

The use of ELF at an international school like CISPA serves the function of meaningful communication between performers, teachers and directors representing a large number of different mother tongues. However, from the very founding of the school, the creative and artistic aim of using ELF in performance has also been to develop a methodology, which allows performers to approach the ELF in a non-conformist manner and tap into a latent potential of the language, thus using ELF as a playground for artistic exploration, rather than an obligatory means of functional communication.

In terms of language competences, students are accepted onto the training based on a wider feel for and sense of language(s) rather than measurable English language skills. Naturally, students need to have a certain level of proficiency in ELF, but their musicality, sensuality and body-mind resonance have a higher focus in terms of linguistic expressivity, and are explored in both ELF and their mother tongues in e.g. audition speeches, which are led in a highly physical direction by tutors, thus testing the applicants' ability to tune into a reciprocity between text/language/vocality and embodied, unconscious motifs: stirred-up images and impulses, which I will examine further in the chapter on Movement Psychology.

During the training, text and language explored in this psycho-physical way are an integral part of most classes, however, some classes are specifically designed to deal with the use of ELF, e.g. Rhetorics, Text and Scene Analysis, Phonetics, and Reading Salon, where issues like rhetorical structure, Iogos and pathos, meaning and musicality, pronunciation, articulation, sensuality and flow are tackled. Again, it is important to emphasize that the body-mind insight into language is highlighted over correctness.

An English text is approached in different ways with regards to performing the language:

- As a piece of literature, analysing and practicing the rhetorical features, thought-processes, beats and units, eliciting meanings.

2. Gadamer 1990. 
- As a piece of music, deconstructing it, working intuitively with the vowels, consonants and the sound components. What bodily dynamics do they resonate with? What imaginative and unconscious motifs do they tap into?

The most poignant example of this methodology that approaches language skills from several different angles is the Shakespeare exams (mid second Year). Many students encounter this kind of text for the first time. The tutors prepare for a series of interrelated tasks to work with the students, such as simply eliciting meanings, pronunciation and etymology, helping them build a structure, understand and use rhetoric to read, interpret and deliver the texts. But the encounter with, in many instances, totally foreign words and phrases constitutes an opportunity to approach the text and language with very few morphological and phraseological preconceptions, which means that students have to truly investigate each word and phrase with a child's curiosity; the sound components, musicality, rhythm, images, impulses, thoughts and feelings that they stir up and resonate with. In this way, the hidden, inherent potential of the text and the language may be manifested through embodying its lyricism, musicality, rhythm, and sensuality. Here, embodiment refers to consciously bringing these elements into a vibrating reciprocation with the imaginative and unconscious motifs awakened in the performer. They are articulated through the specificity of the physical and vocal dynamic in movement and speech, gesture and posture, that is the physically and vocally externalized manifestations of the inner landscape.

Thus, students are assessed, not on to what degree they may be able to approximate pronunciation, accent, morphology, or phraseology to native English speaker (NES) standards, but rather on whether they are able to make the representation (rhetorical features, pentameter and articulated meaning) reciprocally complementary with the unlocking of the mentioned inherent potential. This is not about displaying, as in flaunting, the properties of the text and the language, but about embodying and transmitting its unconscious resonance.

This meeting of predominantly non-native speaker (NNS) performers with ELF is a volatile issue of mutual adaptability. Most non-native speakers interact with English with a certain degree of awe: not only the rich and lush language of Shakespeare, it is the language of colonization. Native speakers and non-native speakers alike habitually vent concerns like: "how could I possibly do this language justice?!" The awareness of such lack of formal proficiency often results in an almost subservient attitude towards the language itself. The aim would be for performers to reciprocally inhabit or counter-colo- 
nize the ELF, insisting on their poetic license, which allows their individual voices to be heard, regardless of their potential linguistic incorrectnesses, and lack of intuitive ownership of the language. Ian MacKenzie touches on these aspects in his book English As Lingua Franca, in analysing the "functionality" of meaningful communication and the intuitive ownership of a language: "NNSs (non-native speakers) can acquire a declarative knowledge of an L2 (second language), but this rarely matches the intuitive knowledge of the NS (native speaker) [--] The NS has a linguistic code acquired in early childhood in conjunction with lived experience of the culture attached to the language."3 However, later, he points towards the creative freedom, which may be obtained from a non-conformist attitude to the language: "Instead of restricting themselves to the realizations of NESs (native English speakers), ELF speakers exploit unused latent possibilities of English morphology, syntax and phraseology."4

Although MacKenzie is still mainly concerned with the communicative functionality and linguistic variability of ELF, his discussion nevertheless touches upon what is one of the main arguments of this paper: that ELF may be used as a creative playground for the performers' voices, bodies and minds, and thereby a platform for the expression of their highly diverse identities in vibrant interplay with the constructional aspects of the language. If the performer is able to let go of all conventional and preconceived ideas about what the "Englishness" of her theatrical utterances sounds like, the creative freedom this gives her may enable the ELF to flow as an expressive carrier and container of the voices of the performer's unconscious impulses, thought processes as well as intuitive and emotional states, executed with an acute awareness of the second language as a linguistic construction to be used for artistic purposes.

It seems that this approach of emphasizing a bodily intuitive language, over the constraints of language correctness, in most instances, helps the performers overcome the obstacles normally associated with linguistic expressivity. I believe it is due to the interplay with physical movement, reminiscent of studies into improved cognition through physical education, because it draws nearer to a visceral ownership of the language. It gives the actors the disposition and the license to, for example, replace a word with a gesture, complement a line with a physically abstract echo of an inner state that challenges the immediate meaning of the line, or simply let the text and the utterance

3. MacKenzie 2014, 7.

4. MacKenzie 2014, 2. 
happen with the courage to fail. The daring to fail improves their confidence in their linguistic expressivity and additionally results in bolder and more autonomous acting choices.

\section{MOVEMENT PSYCHOLOGY}

Hand in hand with ELF, Movement Psychology, as a main methodology at CISPA, analyses the reciprocity between our unconscious states and expressive movement, including vocal dynamics. It builds on the ground-breaking work of Yat Malmgren, as developed from his collaborations with Rudolf Laban and John Carpenter. It makes up a comprehensive system, which scrutinizes how unconscious states manifest themselves in expressive movement, including vocality, and, conversely, how bodily movement may awaken and affect unconscious states. The system is deeply influenced by the works of C.G. Jung, especially as regards to its focus on psychological archetypes, persona, extroversion and introversion.

As with all movement techniques, there is a physical ground work of developing the performers' core strength, stamina, honing of senses, body awareness and quality of movement, and the systematic training of physical expressivity within the different spatial dimensions in order to build and continuously expand their expressive register. All these aspects are trained extensively, not only through Movement Psychology, but also through a variety of movement techniques, such as classical ballet, Horton, Gaga and Butoh. However, an essential part of the Movement Psychology training revolves around extensive physical and vocal improvisations in which students examine the reciprocality between, on the one hand, their unconscious impulses, intuitive and emotional states and, on the other, their extroverted physical and vocal manifestations through language.

These improvisations facilitate the creative search for a common artistic expressivity in a multi-national and multi-cultural context, regarding language in a broad sense, including movement, gesture, and vocality. The aim, both in training and in specific rehearsals, is to creatively explore and channel into a specific dramatic context what is "universally human"; what Jung named the collective unconscious: "The collective unconscious - so far as we can say anything about it at all - appears to consist of mythological motifs or primordial images, for which reason the myths of all nations are its real exponents. In fact, the whole of mythology could be taken as a sort of projection of the collective unconscious. [--] We can therefore study the collective unconscious 
in two ways, either in mythology or in the analysis of the individual." 5

In these improvisations, students are suggestively guided towards a state of "active imagination", ${ }^{6}$ where the conscious insights previously obtained through character and text analysis - such as characteristics, intentions, character problem, circumstances, a character's imagined past, relationships, thought processes, themes, ideas, discourses - are explored physically and vocally, by applying what Jung called "mythopoetic imagination".7 Sonu Shamdasani describes this technique of how Jung was "deliberately evoking a fantasy in a waking state, and then entering into it as into a drama. These fantasies may be understood as a type of dramatized thinking in pictorial form.[--] In retrospect, he recalled that his scientific question was to see what took place when he switched off consciousness."8

This alert state of abandoning the conscious is where the performer may reach a pool of transpersonal raw material and channel it through her personal material. It is, of course, impossible to distinguish clearly between what might qualify as "collective" or "personal". After all, Jung himself recognized the "unavoidable influences exerted upon it by the environment." However, what emerges in these kinds of actively imaginative improvisations are movement and vocal patterns, which revolve around yielding (surrender) and contending (fight); exertion of intention (Will); basic emotions (e.g. fear, love, anger, disgust); abstract thought processes, ideas and visions expressed spatially; a reciprocation between introversion and extroversion expressed through the physical oscillation between the two in a continual cycle of adaptability; repetition and ritual. These patterns seem to have an inherent universality, seeing that the multicultural group of performers communicate uninhibitedly within the same dramatic world, exploring the characters and the themes of a play through movement, sound components and deconstructed ELF, gradually introducing longer sequences of text, lending the embodied dynamics to the application of the ELF in the particular scenes.

Thus, these improvisations constitute not only an integral part of the psycho-physical training, but are used as concrete tools in rehearsals, both in terms of exploration of character, scene, text as well as in terms of choreographic sequences created from the movement material, and incorporated in the final performance.

5. Jung 1960/69,152.

6. Chodorow 1997.

7. Jung 2009, 208.

8. Hillman \& Shamdasani $2013,18$.

9. Jung 1960/69, 112. 


\section{ACTION RESEARCH}

Originally used in sociological studies, Action Research merges qualitative and quantitative approaches into one, holistic methodology, ensuring a participatory, democratic process of problem-solving, learning and reflecting among practitioners, teachers and students alike: "Action research [--] offers a dialogical scheme between arts and theory formation that creates a common narrative of the fields and the participants; it empowers artists to become researchers, i.e. to document and reflect on their own creational work, and introduces researchers into the practical knowledge of artistic process."10

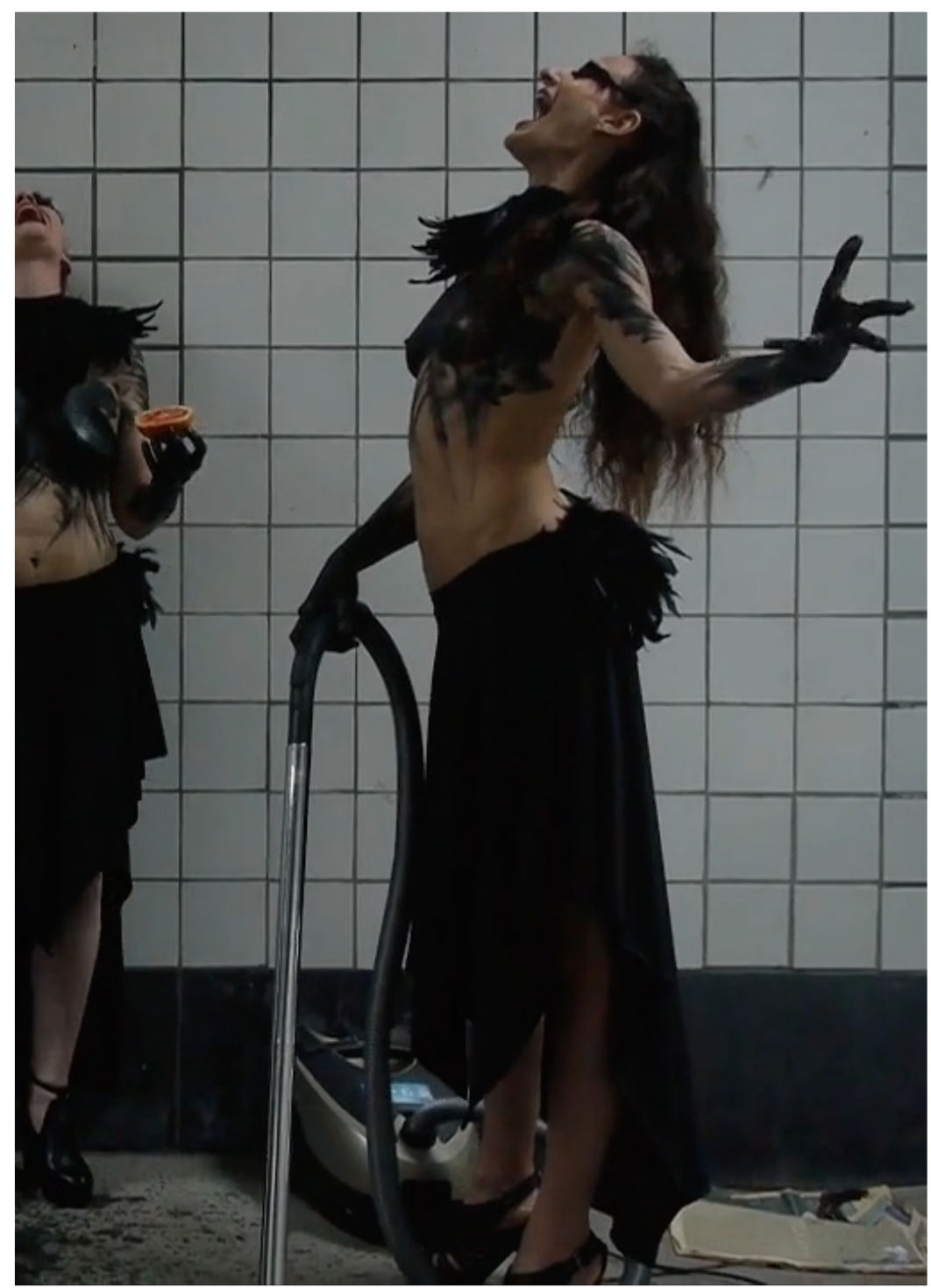

FIGURE 1. Furies. Photographer Nefeli Kyriakidi.

10. Sebestyèn 2016, http://cispa.dk/research/, accessed 5 January 2017. 


\section{REHEARSALS AND PERFORMANCES OF RE:ORESTES.}

Applying the above detailed methodology (English as Lingua Franca, Movement Psychology, Action Research)

Charles Mee's Orestes 2.0 (1992) is a postmodern deconstruction of Euripides' Orestes from which he has "pillaged" (Mee's term) elements of structure, content, characters, myth, and narrative, and mixed in other "pillaged" fragments from the internet, TV, radio and other literature. It is both an exciting and exasperating compilation of tragic pathos and all sorts of material thrown into the pot, ranging from pornography to complex political discourse with the added spice of postmodern, tongue-in-cheek irony.

Like all his plays, the text is available as open source material, making up his (re)making project, the premise of which is that writers, performers, and directors should "feel free to take the plays from this website and use them freely as a resource for [their] own work [--]" since "there is no such thing as an original play". 11

The conception of a postmodern text, furthermore the postdramatic theatre, is embedded in this gesture of the writer - he himself setting up a platform for free rewriting/reconceiving, following Lehman's thought on postdramatic theatre: "[--] it seems it is exactly the omission of an original source/agency of discourse combined with the pluralisation of sending agencies/sources on stage that lead to new modes of perception."12

This postmodern open source approach and negation of the notions of authenticity and originality are totally in line with Mee's main source of 'pillaging': Euripides' Orestes and Ancient Greek mythology. As Mee points out on his website: "None of the classical Greek plays were original: they were all based on earlier plays or poems or myths." ${ }^{13}$ Ancient Greek mythology was in no way canonized. It was the mega-text of the time, like the internet is ours, which was rewritten by each of the tragedians. This was one of the premises of Ancient Greek mythology. Its legacy is one of imperatively urging authors to further explore and rewrite, and through this process, filter it through a new subjective context in a continuous Exphrasis practice. This imperative has been accepted throughout the history of theatre by playwrights ranging from Seneca, Racine, Corneille, Anouilh, and Sartre. The texts have also become a field of exploration for postmodern writers, which is exemplified in Mee's comprehensive list of tragedies.

11. Mee: "the re-making project", http://www.charlesmee.org/about.shtml, accessed 5 January 2017.

12. Lehmann 2006, 32.

13. Mee: "the re-making project". 
Like most projects and teaching at CISPA, the rehearsal, staging and performing process of the production Re:ORESTES adhered to the action-research methodology, thus guiding the performers to concurrently rehearse, record and reflect on their work (in writing, collaging, photographing, blogging and video-logging), which was shared between all participants, thereby creating a common narrative in the form of a shared pool of creative material informing the further process. The original four steps of action research were: diagnosing, planning, taking action and reflecting, and they took the following shape during the Re:ORESTES rehearsals:

(I) Individual reading of the texts (Mee and Euripides)

(II) Doing a common read-through

(III) Discussing in depth the plays and the relevant myths

(IV) Seeking out additional texts, songs, poems etc.

(V) Associative writing (inspired by the received and collected material)

(VI) Sharing these writings

(VII) Improvisations (inspired by the received and collected material)

(VIII) Remoulding/rewriting scenes based on the preceding process

(IX) Rehearse scenes

(X) In most instances repeating cycles (IV) to (VIII) before the next rehearsals of specific scenes

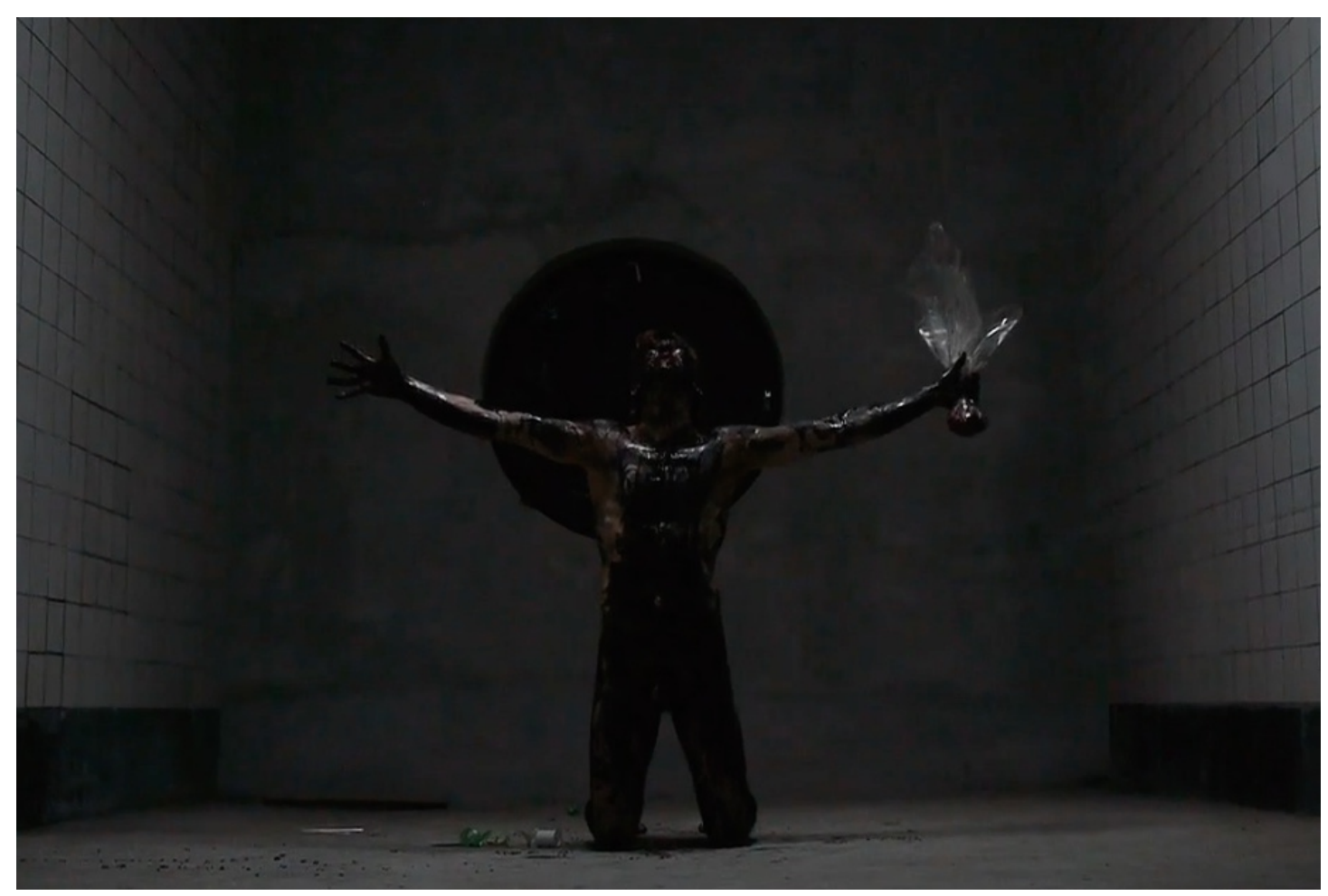

FIGURE 2. Orestes holding his mother's heart. Photographer Nefeli Kyriakidi. 
The title, I as the director chose for our production (Re:ORESTES), obviously alludes to Mee's imperative of Re-making and Re-viving, but equally to the Re: ("Regarding") of the email Re-sponse or Re-ply. It seems to me that the internet has the same structure as Ancient Greek mythology: a non-canonized, huge mega-text, which everyone adds to and subtracts from in a shared mega-narrative, and so I wanted to obligate the actors to investigate their personal/creative responding to, and being responded to, by the received material, like an email correspondence going back and forth.

Therefore, I considered the artistic premise outlined by Charles Mee an ideal opportunity for the CISPA students to explore several creative fields:

- Their identities (the personal unconscious: cultural, social and national identity, and the collective unconscious within the conscious framework of the psycho-physical actor training and rehearsal process)

- Scenic transformation, through the received input of the written material, including Mee's source material, in particular Euripides and the mega-text of Greek mythology

- The rehearsal process of adding, revising and recreating.

For this recreating process, most active phases of the rehearsals started from step (V): the actors undertook associative writing in ELF with the non-conformist approach of disregarding correctness, or in their mother tongue, which was subsequently translated into ELF for the sharing of the material. For the associative writing, the students used learnt techniques in relaxation, tapping into a daydreaming state of mind, employing their active imagination, and writing down or recording their free flow associations. I gave them as a starting point and focus: depicting actions and objects. This "automatic writing" was the performers' immediate, creative response to the received material.

By sharing the associative writings and other material created or sought out (VI), the actors took in and connected with each other's contributions, thereby letting their stories/micro-myths meet, join up and become a shared mythology, however fragmented. From this shared and spun web of a common mythological narrative, material was picked that would inform the rewriting of the speeches and dialogues, and inspire characters, performance, interpretation, scenic language and style (VIII). Physical improvisations (VII): the physical manifestations of this re-imagined shared mythology in the form of Character Object Exercises, which are rehearsed improvisations involving objects and actions, specific to character and the imagined world. Objects and actions that were derived or inspired from the associative writing connected the performers and characters to the re-imagined mythological mega-text. 


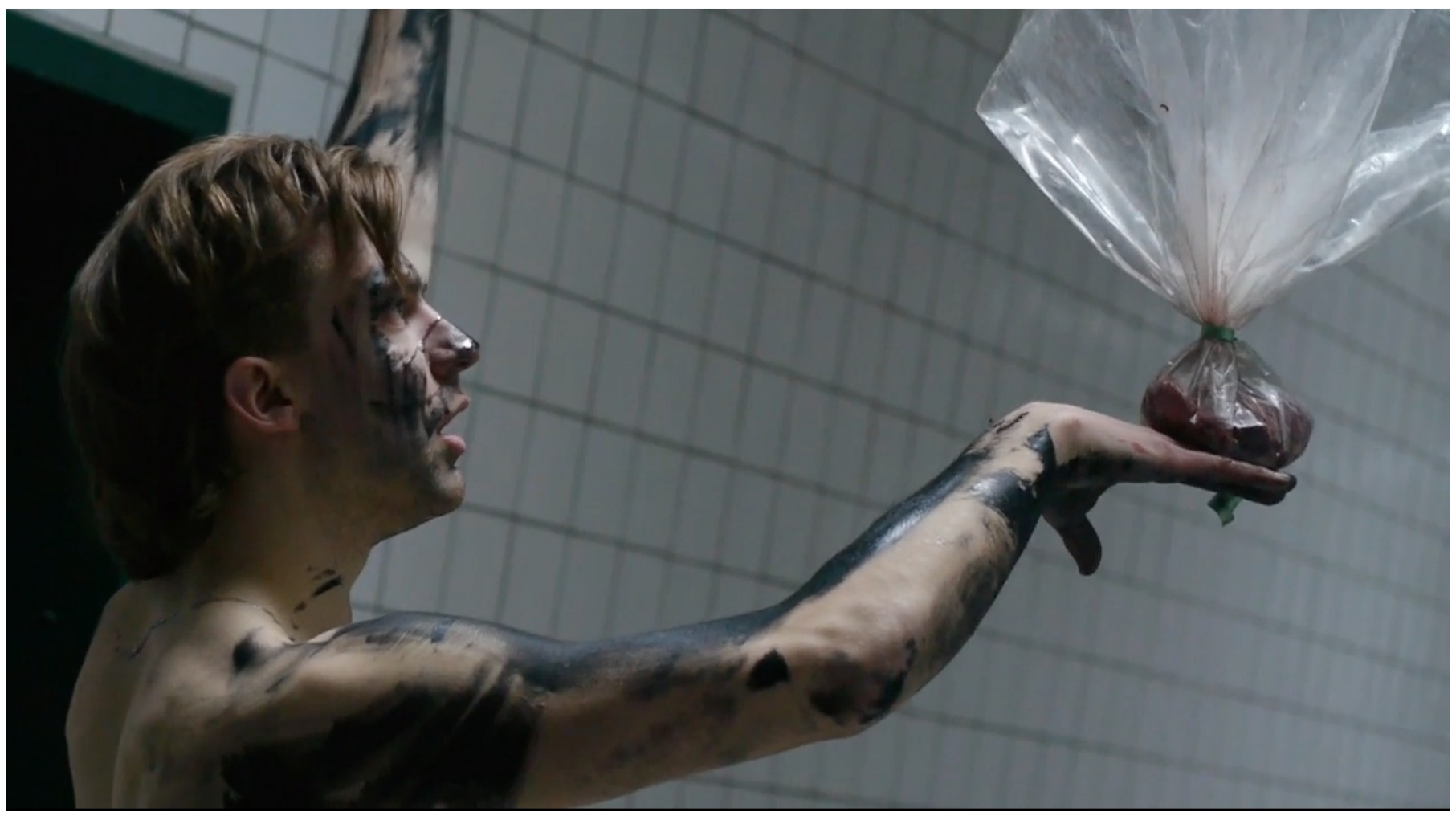

FIGURE 3. Orestes holding his mother's heart. Photographer Nefeli Kyriakidi.

Most actors then used all this as inspiration for a new cycle of associative writing and improvisations. These improvisations tested the writings through character interactions using movement, sound components, line fragments, and gradually longer sequences of text in ELF. Furthermore, they allowed the performers to explore their characters' objectives, thought processes, intuition and feelings, physicality, shadow moves, morphology and phraseology. In collaboration with me, the director, the writing and the characters would eventually be harnessed considering circumstances, context, scenes, narrative, scenic expression and style, in order to fit into the overall production. Eventually, the production, rather than Mee's postmodern deconstruction of the story line and characters, was characterized by a metamodernist suspension between a fervent yearning for grand narratives and a bathetic deflating in the vein of Vermeulen and van den Akker: "[--] this modernism is characterized by the oscillation between a typically modern commitment and a markedly postmodern detachment."14 


\section{EXAMPLES OF THE METHODOLOGY:}

The "Queen's English" Cassandra-monologue, along with the poly-glottal Fury-monologue

An example of this transformative remoulding process was that of a student, cast in the role in Mee's Orestes 2.0. of Tapemouth Man, an isolated, mysterious figure, tied up in a wheelchair with duck tape over his mouth, who occasionally manages to free his mouth of the tape, hence plunging into rambling tirades, which nevertheless serve as perspective to the Orestes/Electra narrative with fragments of political and academic discourses.

The first circle of associative writing and character improvisations led us towards reconstructing the character as Cassandra, a prisoner of war after the murder of Agamemnon, left to rot in a world, which resembles a field hospital, tended to by nurses, whom we recreated as Furies.

Very early on in the process, I made the directorial choice that the entire theatre would be the domain of the Furies that were Grand Guignol intriguers, whose very nature was to cause Dionysian mayhem around them. They would orchestrate the whole performance and even production from the initial greeting of the audience in the foyer, over directing and stepping in and out of the scenic action, to pulling the plugs of the stage lights and starting to clean the space, while impatiently asking the audience to leave. Throughout the performance, the Furies took the shapes of an array of characters, instrumental to the staging of the fragmented narrative of the haunting of Orestes, the trial of Orestes and Electra and the attempted escape of the two siblings along with their lover Pylades.

Among their patients in the field hospital/asylum were soldiers with posttraumatic stress disorder, Cassandra and Orestes on a crazed Hamletian mission of making sense of it all and taking appropriate action. Every time he found some direction and determination, however, the Furies pulled another carpet from underneath his feet.

Like the mythological character, Cassandra was bestowed with acute psychic and prophetic powers, which produced one splintered vision after the other. She was tied up in her chair and every time she managed to free her mouth of the duck tape, her seemingly undecipherable rants were met with either blasé annoyance (the Furies), or volatile exasperation (the traumatized soldiers). With every tirade, the Furies had a new humdrum exchange about the endlessly repeated task of shutting her up, and every time, eventually, one of them routinely covered her mouth again with duck tape, and so the staging of the Furies could be picked up and continued until Cassandra again 
managed to free her mouth.

In one sequence, Cassandra singled out individual audience members as casualties of wars, encompassing both the Trojan War, World War I and the 9/11 attacks, conveying the details of their deaths to them. In another, she delivered a fragmented analysis of the way the nation state inscribes itself into the bodies of its citizens through war, calling upon the audience to free themselves from the nation states' embedding themselves into the bodies of both the individual and the collective. The actor devised/rewrote this cry for freedom from Sophia Scholl's leaflet writing. ${ }^{15}$

The last fevered vision blurred the lines between (1) an analysis of the fear of the enemy being a much more devastating threat than the actual losses caused by that enemy, (2) the embodied voices of the war monger of all times reacting pre-emptively to that fear, and (3) the images of her own imminent execution, carried out at the end of the speech by a delirious soldier, who was tipped over the edge by Cassandra's tirades.

The actor playing Cassandra had several cycles of rewriting and rehearsals, where, through guided improvisations around her proposal, she would adjust the text to become more and more organic and concise. This process went on throughout the whole rehearsal process, so she travelled back and forth: in the beginning the associative writings sprung from Mee's text, but as the network of accumulated material, exercises, objects, actions, thoughts and symbols grew ever wider, her writings were increasingly informed by this created and recreated own mythology of the rehearsals right into her final performances. In this sense, not only her constant reshaping of the text, but also her reshaping of the rehearsal process itself became an incorporated part of her performance.

In the end, the actor reached a set text, which she truly was the channel of, rather than the author of, just like Cassandra is the channel of received images transmitted from a shared pool of the collective unconscious.

15. Sophia Scholl was a German student and political activist within the White Rose non-violent resistance group in Nazi Germany. 


\section{AN EXCERPT:}

[--] Like the infinite pulling of the trigger

It is impossible to recognize

His face I can't see his face

I mean the face of the enemy

It can look like anything

Like a horse I tell you like a god damn Trojan horse

I tell you the anatomy of a horse

It's a god damn nightmare

I tell you we are fighting the war on terror

Our towers are burning, collapsing and

Falling because of a god damn horse

And the bullet is released

It's leaving the chamber

it's leaving the barrel

it's leaving the muzzle and open mouth

It's in the air

it's in the hair

it's in the skin

it's in

Scratching the scalp

breaking the scull

scattering

taking the veins

[--]

On its way

opening the head

the door of the dead

it's out

And the bullet is out

out in the open

the insides are out

out in the open

the open is in

inside the open

and in the open the insides are inside out

collapsing and falling

collapsing and falling

into who you were

who you were?

falling into the forgotten

collapsing into the pool

into the cold and cool

into the boiling pool

of the forgotten ${ }^{16}$

The circles of rewriting and rehearsing, which the actor playing Cassandra went through in a constant dialogue with the ever-growing shared mythological mega-text of the production, was a process of linking the familiar with the alien, the individual with the collective, for example manifested in the compounding of the actor's personal, political ardour with the primordial ima-

16. The role of Cassandra was devised and performed by Julia Cechal. 
gery of fear and existential collapse. Movement work having been a part of the textual/linguistic exploration and transmitting a text articulating an extreme bodily experience, the actor was eventually tied up in performance, unable to move, thus resulting in a highly physically charged language, which became the movements, indeed speech acts. ${ }^{17}$

The actor is a highly educated, Swedish/Czech woman, who oozes cultural breeding and sophistication also in her use of ELF. We made the choice to push towards Received Pronunciation (RP), i.e. "the Queen's English", to experiment with how this would be perceived in this character. The result was one of inbuilt contradiction: since RP is the accent of official authority, the ruling classes and the law, the rambling visions of this tortured, tied-up and gagged character maintained a sense of jurisdiction and dominion, while bursting at the seams with potent, embodied imagery channelled into the language, and the trace of a Swedish/Czech accent, which gave a niggling dissonance to the otherwise pitch-perfect RP.

As a parallel and antithesis to the English monologue of Cassandra, one of the Furies performed a part in a combination of her mother tongue and ELF.

The Furies, as characters, do not feature in Mee's Orestes 2.0, so the performers that I cast in these roles went through a similarly radical rewriting and remoulding process as the performer playing Cassandra. Their textual starting point in Mee's play was that of other characters that they would shapeshift in and out of during their own imagined staging of "Orestes, the tragedy". A major part of the performance became the farcical trial against Orestes and Electra, orchestrated by the Furies. One of the Furies thus performed the role of the Judge (occasionally alias the Prosecutor). This performer is Greek and we chose to experiment with introducing Greek text into the call-and-response dialogue with the English source material. Among many other sources of inspiration she chose to dig into her cultural and national heritage to revisit her childhood curricula. Thus, she introduced into the shared mega-narrative a number of Greek texts, both Ancient and modern. She would use both direct extracts from Euripides' Orestes and rewritten sequences.

Subsequently, she described her process of inhabiting the Greek and English language respectively as similar in terms of embodying the text through memorizing, massaging, awareness and exploration of the percussive and rhythmic elements, and coalescing her unconscious states with the organic sound components of the language. She specified that the over-articulated digging into the language unlocked a ritualistic power, which she used as 
an artistic choice in the Fury's way of conducting the farcical trial. Throughout, while different witnesses and speakers put their case forward (e.g. Pylades and Menelaus), the Fury would sit in her Judge's armchair mumbling and chanting a mesh of English and Greek, a text that the actor had evolved herself through the process of responding to and rewriting the sought-out text, weaving together lines from Euripides' play in Greek with cliché court phrases in English. In rehearsal as well as in performance, she would develop and jam over the (bi-)linguistic patterns, thereby creating a menacing soundscape of intertwined linguistic, rhythmical and percussive components, underlying the different testimonies.

\author{
AN EXCERPT:

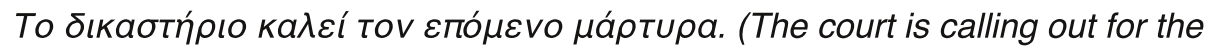 \\ next witness).
}

Do you solemnly swear to tell the truth, the whole truth and nothing but the truth, so help you God? Proceed!

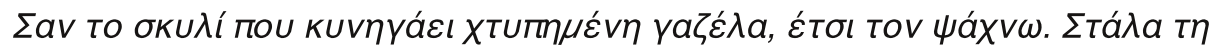

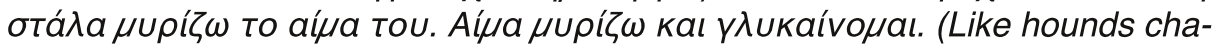
sing a wounded fawn, I track him by the drops of blood he sheds. I smell human blood - I could laugh for joy!).

Silence in the courtroom! Are you aware of the penalties for perjury?

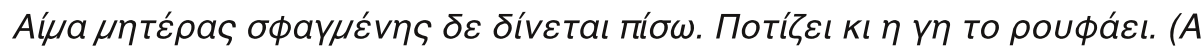
mother's blood, once shed, soaks in the earth and can't come back again)

I rest my case. Has the jury reached a verdict? We have, Your Honor. What say you?

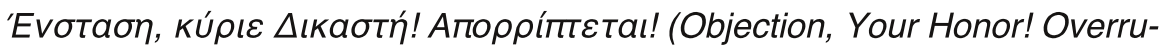
led!). ${ }^{18}$

From the initial self-consciousness of using the Greek language in rehearsals, further on in the process, she experienced a liberating sensation of being allowed to take the Greek sequences in any direction in terms of delivery and interpretation since no one could hold her "accountable". This aspect carried through into the performance situation, where she maintained a liberated, playful approach in her deliveries to the audience. In her own words, the audience became like a group of children that she was playing a game with, the rules of which they didn't quite understand. She would feel empowered by controlling, challenging and manipulating the nearby audience in their uncomfortable position, which was all the more exposed by the fact that they had from the outset been immersed in the world and addressed as patients,

18. The role of Fury/Judge was devised and performed by Georgina Koutsaimani. 
students and jury members, and sat within reaching distance of the actor.

This prompted different kinds of reactions from the audience: unsettled, nervous laughter; annoyed defensiveness; ignoring; and intense interest from others, who would apparently insist on trying to decipher some kind of meaning from speeches, they clearly didn't understand. From feedback given to the actor subsequently, we know that these people would tune in on intuiting the weight that the utterances carried, the intonations, and the rhythmical and percussive qualities of the delivery, putting it in context with the rest of the goings-on, the atmosphere, the scenography and costumes, the choreographed gestures etc., and so divining some sort of significance.

\section{CONCLUSION}

The varied national and cultural backgrounds, mother tongues, educations and social environments of the CISPA students heavily influence any rehearsal process and production, but particularly in the case of a rewriting and remoulding process, where all these invested identities interlace and affect each other in a common mega-text. In Re:ORESTES it resulted in creations like the Furies, whose embodiments of the dramatis personae included the Judge (Greek daemon goddess meets Rumpole of the Bailey), Menelaus (Icelandic populist politician meets King of Sparta) and Female Witness (chthonic Tinder goddess), all amalgamations of the familiar with the alien and the personal with the collective.

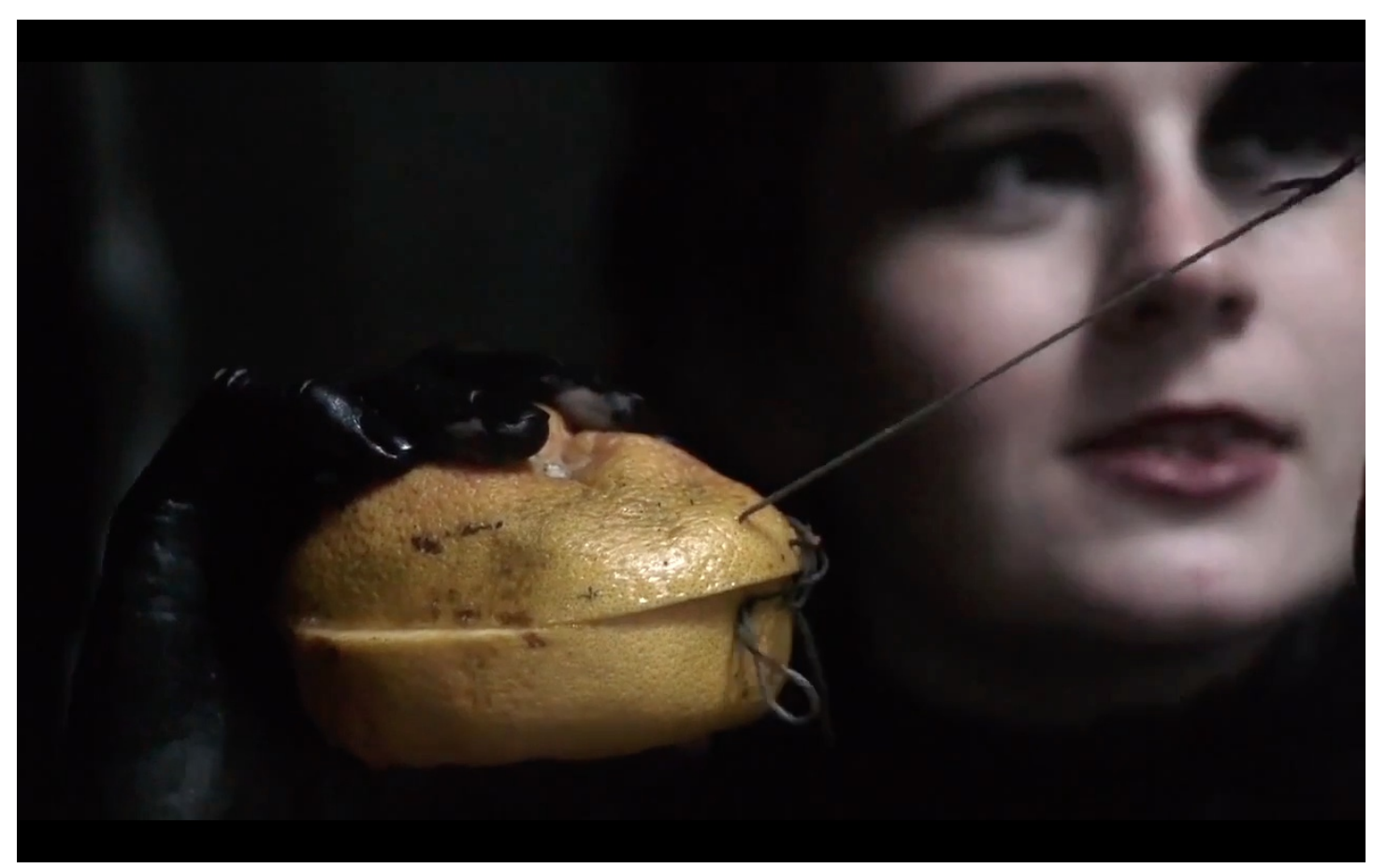

Figure 4. Fury. Photographer Nefeli Kyriakidi. 
This recreated mega-narrative bore the identity stamp of all of the individuals of the cast and their diverse cultural horizons, but also, through a common effort of dialogical mediation, material emanating from a common, pre-lingual unconscious beyond the conceptual limitations of individual, human consciousness. Substance embedded in the mythological raw material, which, through the cycles of rewriting, rehearsing and improvising, was captured and evolved (more or less successfully) into an artistically expressive mega-vocabulary, which I believe is the essential quality in all works of art that we resonate with across cultural divides. In my experience, this pre-lingual, primordial imagery is not fixed or unchangeable when it interacts with the individual's cultural horizon. When the depicted process is successful, it may be channelled, moulded and articulated within ELF, giving unanticipated new life to the language, a morphological and phraseological gutsiness, which doesn't adhere to "correct" native English speakers' standards, but which may, nevertheless, add to the artistic value.

The hosting of the process of fusing the personal with the collective can be a debilitating experience, especially for the gifted and fairly inexperienced performer. In the case of the actor playing Cassandra, the performance reached an extraordinarily high artistic level, but it was a personally exhausting process for the actor due to the painstaking process of, like Cassandra, lending and re-lending herself body, mind and soul to imagery that was channeled from beyond her conscious limitations. The Greek performer experienced a similar, but more enjoyable audacity when she freed herself from "accountability" and could yield completely to a playful approach to her performance and to the audience. With this approach, performers may dare to "fail" miserably, trusting that in this "failure" may emerge a gateway to the truly original, which is not immediately accessible to us, allowing ourselves to confidently play a game, the rules of which we don't understand.

\section{References}

Austin, J.L. 1975. How to Do Things with Words, 2nd eds. J. O. Urmson and Marina Sbisà. Cambridge, Massachusetts: Harvard University Press.

Chodorow, Joan (ed.) 1997. Jung on Active Imagination, a collection of $C$. G. Jung's writings on active imagination. Princeton: Princeton University Press. 
Gadamer, Hans-Georg. 1990. Wahrheit und Methode: Grundzüge einer philosophischen Hermeneutik in Gesammelte Werke Bd.1: Hermeneutik I, Broschiert.

Hillman, James \& Shamdasani, Sonu. 2013. Lament of the Dead:

Psychology after Jung's Red Book, New York: W. W. Norton \& Company.

Jung, C. G. 2009. The Red Book: Liber Novus. Edited by S. Shamdasani, tr. M. Kyburz, J. Peck and S. Shamdasani. New York: W. W. Norton.

Jung, C. G. 1960/69. The Structure and Dynamics of the Psyche in Collected Works. Vol. 8, 2nd ed. Translation Gerhard Adler and R. F.C. Hull. Bollongen Series XX, Princeton: Princeton University Press.

Jung, C. G. 1953 (1916). The Structure of the Unconscious in Collected Works, Vol. 7. Two Essays on Analytical Psychology, London: Routledge \& Kegan Paul.

Lehmann, Hans-Thies. 2006. Postdramatic Theatre. London: Routledge.

MacKenzie, Ian. 2014. English as a Lingua Franca - theorizing and teaching English. London: Routledge.

Mee, Charles. "the re-making project", http://www.charlesmee.org/about.shtml, accessed 5 January 2017.

Sebestyèn, Rita. 2016. Actor Training in a Globalized World; research methodology and innovation: action research. http://cispa.dk/research/, 5 January 2017.

Vermeulen, Timotheus - van den Akker, Robin. 2010. "Notes on metamodernism" in Journal of Aesthetic \& Culture, Vol.2, 2010, 1-13.

\section{VIDEOS}

Re:ORESTES, 2 min video: https://vimeo.com/1570285162

Re:ORESTES, Trailer: https://vimeo.com/1271974293

Re:ORESTES, Behind the scenes:

https://www.youtube.com/watch?v=3Fsm_fo1bzg

All videos by Nefeli Kyriakidi.

\section{THE AUTHOR}

Lars Henning trained as an actor at Drama Centre London (University of the Arts London). His mentor and predecessor was Yat Malmgren, who developed in collaboration with Rudolf Laban the system of Movement Psychology. He performed in numerous productions nationally and internationally, before starting his directing and teaching career in 2000. Since then, he has taught and directed over 30 theatre productions in Denmark, England, Scotland, Canada, Egypt, Iceland, Norway and Sweden. Currently, Lars Henning is Artistic Director at Copenhagen International School of Performing Arts. He teaches Acting Technique, Movement Psychology, Classical Text and Theatre History for all three years, and is responsible for planning, development and implementation of training content. 